\title{
THE BOSNIAN ISLAMIC COMMUNITY AND ITS POSITION ON INTER-RELIGIOUS DIALOGUE, INTERNATIONAL LAW, AND THE NATURE OF BOSNIAN SOCIETY
}

\author{
Ahmet Alibasic \\ Faculty of Islamic Studies \\ University of Sarajevo
}

\begin{abstract}
This essay presents and discusses The Platform of the Islamic Community in Bosnia and Herzegovina for Dialogue (2006), a programmatic document of the Islamic Community in Bosnia and Herzegovina. Its first section sets out basic principles for Bosnian Muslim participants in inter-religious dialogue on religious diversity and coexistence. The second one deals with inter-ethnic and international relations, human rights, and violence. The third section highlights the Bosnian Muslim perspective on the 1991-1995 war in Bosnia and Herzegovina and the post-war restoration of a pluralist society. The Platform offers a rare but clear statement of the Islamic Community's position on dialogue and cooperation and was reasonably positively received by Christian theologians in the region.
\end{abstract}

Keywords: Islamic Community in Bosnia and Herzegovina; Human Rights; International Law; Inter-religious Dialogue; Coexistence; Justice

\section{Introduction}

Bosnia and Herzegovina is a small Southeast European nation of three and a half million people. Its statehood dates back to the $12^{\text {th }}$ century. The Ottomans conquered the medieval Bosnian Kingdom in the $15^{\text {th }}$ century. Over the next two centuries, about half of its population became Muslim. The Ottoman era ended in 1878 when the European powers entrusted unruly Bosnia to the Austro-Hungarian Empire to pacify. The sultan remained Bosnian de jure sovereign until Austria annexed Bosnia in 1908. After World War One the country became part of the newly established Kingdom of Yugoslavia and after World War Two continued as one of the six republics of socialist Yugoslavia. In the process of the dissolution of Yugoslavia in the 1990s caused by irreconcilable nationalist claims, Bosnia became an independent state on 1 March 1992 when about two thirds of its citizens voted for independence in a referendum (Malcolm 1994). However, most Bosnian Serbs objected to independence and started a separatist war aided by neighbouring Serbia. In the course of the war, about one hundred thousand people were killed, mostly Muslims. Millions were forced to leave their homes. In at least one region, that of Srebrenica, international courts ruled that genocide against Muslims was committed by units of the Bosnian Serb army and police. The three-and-ahalf-year war ended in late 1995 with the Dayton Peace Agreement, which created a complex administrative structure. Although the word "secular" is not used in the Bosnian 
constitution, state and religious affairs are separated, and, for all practical purposes, Bosnia is a secular state. The three main religious organisations are the Islamic Community (51\%), Serb Orthodox Church (31\%) and Catholic Church (15\%) (Carnegie 1996; Hoare 2017).

The Islamic Community in $\mathrm{BiH}(\mathrm{ICBH})$ is an unusual Muslim organisation. Established in 1882 by the Austro-Hungarian Empire for the administration of Islamic religious affairs in Bosnia, it developed gradually to become the sole voluntary Islamic organization in the country and is now responsible for running most of the mosques and appointing all the imams. Autonomous and independent of the state or any international Islamic organisation, it has no disciplinary authority, but its activities nonetheless include organising rituals, providing Islamic education, managing Islamic endowments, publishing periodicals and books, and running charities. It is educationally and financially independent, financed by waqfs (endowments), membership fees, zakah, sadaqat al-fitr (charitable giving), different forms of tithe or charitable donation, revenue from its for-profit agencies, gifts, and donations, from in-country and abroad.

The ICBH has a hierarchical structure with a grand mufti (rais al-ulama) at its head but is nonetheless managed in what can be described as a semi-democratic fashion. There are approximately 2000 mosques in Bosnia and Herzegovina $(\mathrm{BiH})$. These are the ICBH's grassroots institutions. Around 650 were totally destroyed and a further 530 damaged during the Bosnian War of 1992-1995, and some have yet to be reconstructed. The ICBH's main educational institutions are the Faculty of Islamic Studies in Sarajevo (est. 1977 and now part of the University of Sarajevo), the Gazi Husraw-bey Library (est. 1537), two Islamic Teachers' Faculties, the Gazi Husraw-bey madrasa (est. 1537), seven other madrasas in Bosnia, Croatia and Serbia, and the First Bosniak Gymnasium, located in Sarajevo. The Community has its own Radio and TV stations. There are also a number of Sufi orders (tariqahs) affiliated to the ICBH.

Inter-religious dialogue (IRD) and cooperation are major areas of the ICBH activity and have taken on a special significance for the country's multi-faith society under postconflict conditions. Since the Balkan wars of the 1990s, dialogue has taken place in a context of reconstruction and reconciliation and of religion-inspired terrorism and the war on terror. ${ }^{1}$ In 2005/6, the ICBH prepared a document, The Platform of the Islamic Community in BiH for Dialogue, to provide guidance to the many Bosnian Muslim participants in inter-religious dialogue and cooperation and set out its general position for potential interlocutors. The Platform is presented in English here for the first time. ${ }^{2}$ Its first section sets out basic principles for interreligious dialogue on religious diversity and coexistence. The second one deals with international law, inter-ethnic and international relations, human rights, and violence. The third elaborates the ICBH's perspective on the 1991-1995 war and the success of the post-war restoration of a pluralist society, or rather the lack of it.

The "War on Terror" or "Global War on Terrorism" is a popular name for the US-led effort against mainly Sunni Muslim terrorist networks around the globe. The term proved to be contentious and was usually avoided in official discourse.

2 The Bosnian text is available at https://static.islamskazajednica.ba/fetve-i-rezolucije/5756-nacrt-platformeislamske-zajednice-u-bih-za-dijalog (Accessed 11 July 2019). 


\section{The Islamic community in Bosnia and inter-religious dialogue}

The Platform opens by stating that, since the time of the Prophet Muhammad (peace be upon him), Muslims have recognized the right of non-Muslims to believe and manifest their faith freely. This right is given to them by God and is a protected value under Sharia (Islamic Law). ${ }^{3}$ The ICBH advocates for freedom of religion throughout $\mathrm{BiH}$. Such freedom is an important aspect of modern democratic standards and a centuries-old tradition in Bosnia and Herzegovina. The ICBH's position on the nature of the relationship between the Bosnian state and the various religious communities accords fully with this view. The ICBH subscribes to Article 9 of the European Convention on Human Rights (ECHR), which includes the decriminalization of apostasy and opposition to coercion and discrimination. This commitment places the ICBH, which represents $51 \%$ of the population, in the same position as the Jewish Community, which represents fewer than a thousand members, or the Catholic Church, which represents about $15 \%$ of the population.

The Platform affirms the ICBH's openness to inter-religious dialogue (IRD), primarily with representatives of the other monotheistic religions, but also with new religious communities in Bosnia, such as Evangelical churches. The ICBH considers dialogue with traditional churches and religious communities in $\mathrm{BiH}$ of particular importance, but is not willing to enter into dialogue with communities or individuals that insult or disparage ,Islamic teachings. Each community and church is called upon to condemn and sanction individuals and groups within it that spread religious hate or encourage intolerance and bigotry toward the followers of other faiths or beliefs.

This emphasis on dialogue with other traditional religious communities is context driven. About $90 \%$ of Bosnian citizens profess one or other of the traditional religions. In a marked departure from the scepticism expressed by many eastern European Christian communities, however, the ICBH also declares its openness to engage in dialogue with new religious communities. In practice, this has often meant dialogue with Protestant churches. Communities considered heretical by many Muslims (e.g. the Ahmadis) are not present in any significant numbers in Bosnia, and in practice there has been little dialogue, though certain initiatives have reportedly been made from within those communities towards the ICBH.

The call for each community to deal with its own radicals and extremists is in line with the ICBH's commitment to fighting extremism within its own ranks and a challenge to the other communities to do the same with their extremists. Given the degree of radicalisation of some clergy, including bishops, within the Serbian Orthodox Church during the 1990s, this was a formidable challenge (Tomanić 2001). While Muslim radicals are an unpopular and marginalised minority in the Muslim community, with 96\% of Bosnian Muslims against violence in the name of religion (Pew Research Center, 2013:29), radical positions have been expressed by leading figures in other religious communities, who have maintained cordial relations with war criminals. One example is the former bishop of Bijeljina, Vasilije Kačavenda (B.Z. 2020; Marković 2020).

The Platform also discusses the level at which IRD should take place, or rather allows for it to take place at any level, from educational institutions to local clergy and believers,

For more information, please refer to Alibašić, A. 2007. The place for others in Islam. Comparative Islamic Studies, 3(1), 98-123. 
by various modalities, including gatherings of believers. The academic level is useful for tackling issues pertaining to religious teachings and tradition, while the popular level is more useful in treating issues of general interest. Any issue may be discussed, but joint prayers are not to be organised between the followers of different religions for doctrinal and ritual reasons. The textbooks used in religious and public schools, as well as faculties, should include materials on traditional religions and religious communities in $\mathrm{BiH}$, drawn up by their representatives.

This position reflects a certain confidence and runs counter to the more restrictive approaches to IRD taken by other Bosnian religious communities, who would prefer it be confined to approved clerical circles. The ICBH does nonetheless, advocate that IRD be adjusted to the group taking part in dialogue. A topic or activity appropriate for academics might not be the best topic for ordinary lay believers. The reference to religious education textbooks was in the context of the textbook revision process of the early 2000s. Textbooks written during the 1990s often contained derogatory content about other ethnic and religious groups such as calling Bosnian Muslims "Turks" (Alibašić 2009). The ICBH's reservations towards joint prayers are a sign that, despite its generally liberal attitude to IRD, limits nonetheless remain. The main reason for this is that some conservative Muslims consider joint prayer to verge on syncretism. By making such concessions, the ICBH was no doubt trying to keep them within the prodialogue camp, which is probably prudent, as Islamic organisations that press progressive agendas too fast can lose their following. Negotiating such issues internally is ultimately more conducive to IRD than forcing a progressive approach that alienates significant segments of the community.

This section of the Platform ends by stating the ICBH's intention to continue upholding values of inter-religious coexistence, tolerance, and respect for different beliefs on Bosnia's path towards higher levels of security, stability, and the cherishing of difference in society. Such an aspiration might have the ring of cliché elsewhere. However, in the Bosnian context of the day, it is a highly meaningful one, insofar as the Balkan Wars of the 1990s boiled down to a struggle between acceptance of coexistence and refusal of the same. Extremist Serb separatist leaders repeatedly insisted that different ethnic and religious communities could not live together. The government in Sarajevo responded with a consistent "Yes, we can" (Assembly of the Republic of Srpska 1992; Pejanović 1999:293-294).

\section{International law, human rights, and violence}

Written in the wake of the "War on Terror" after 9/11, the Platform declared that

the ICBH is in favour of the peaceful resolution of any dispute between states. Being rooted in the Islamic position that all people make up a single community, the ICBH strongly condemns any form of aggression against, hegemony over, or exploitation of the poor by the powerful. Just as it considers the rule of law within individual states crucial, the ICBH believes [that] international relations must be

4 The "War on Terror" or "Global War on Terrorism" is a popular name for the US-led effort against mainly Sunni Muslim terrorist networks around the globe. The term proved to be contentious and was usually avoided in official discourse. 
subject to international law. The ICBH expects the Muslim peoples of the world to contribute fully to the development of international law and incorporation within it of Islamic principles and values.

This was a balancing act between support for the anti-terror efforts of the Bosnians' most powerful allies, the United States and her allies, and criticism of how the fight was being conducted, especially in Iraq (Haass 2013). The Platform then turns to human rights, declaring that:

The protection of human rights is a major legacy of contemporary legal development. The ICBH stresses in particular the need for the full exercise and protection of freedom of religion and beliefs and the eradication of all forms of discrimination, particularly on these grounds. Efforts to realise human rights and freedoms must be based on principled action and the cause must not be allowed to become the foreign policy tool of particular states or be applied selectively for partial interests.

This unconditional support for human rights was due to the recent history of mass human-rights violation in the Balkans, of which Muslims were by far the most frequent victims. Elsewhere, Muslims may still have doubts about the Islamic justification for some human rights (Mayer 2018). However, because of what they have suffered, most Bosnian Muslims do not have those doubts. Life has taught them what books could not. The Platform also notes that campaigns to promote human rights are not always based in nobility, however, as they are often political tools in the hands of the powerful. Turning to certain major sensitive issues in the post-9/11 world, the Platform is clear:

The ICBH rejects and condemns the use of violence. It is particularly important to emphasize this in an age when individuals, groups and states use terrorism to pursue their political agenda, sometimes even invoking religion to do so. Understood as an illegal use of force against prohibited targets or of prohibited methods, terrorism represents the same thing in peacetime as war crimes do in wartime. The ICBH rejects all such types of violence and considers them crimes punishable under both divine and human law. The ICBH also condemns state terrorism, which can have severe consequences, given the state monopoly over force.

The ICBH particularly condemns individuals or groups that invoke Islam when performing terrorist acts. They represent neither Islam nor the Muslims of the world. Such individuals are perpetrating violence against Islam and Muslims as well. The fight against terrorists must be conducted by legitimate means.

The comparison between terrorism and war crimes is noteworthy. It was meant to ensure that Bosnian Muslims reading the Platform were in no doubt of the proper Islamic position on terrorism. For some of them, influenced by conspiracy theories or disapproval of the many injustices done to Muslims around the world, might conceivably have entertained other ideas about terrorism, as occasionally occurs. However, none of them are in any doubt that war crimes are wrong as they had been at the receiving end of them. The fact that Bosnian Muslims remain world leaders in the rejection of violence 
suggests that this anti-terror discourse in Bosnia has been convincing (Pew 2013:29). The Islamic Community elaborated its anti-extremism and anti-violence positions in a number of other documents, including an analysis and theological deconstruction of extremist ideology conducted in 2018. That document lists 30 anti-extremism measures and activities undertaken by the Community since 1997 (Jusić 2018:8-12). ${ }^{5}$ This section of the Platform closes with a condemnation of Islamophobia:

The ICBH further condemns Islamophobia generated by irresponsible politicians or the media. The disastrous consequences this has given rise to in the past, thanks to prejudice, conspiracy theories, and allegations of the responsibility of entire ethnic or religious groups are well known. Responsibility must always be individual and a distinction made between a teaching and distortions of it.

Once again, war experience played a role in the formulation of the ICBH position in at least two ways. First, it condemns the fear-mongering so common in the post-9/11 world as playing with fire to be recognised and stopped as early as possible. Even today, the speed at which Yugoslav society collapsed, remains a major puzzle of the Yugoslav wars. Just a few years before the outbreak of violence, Yugoslav society seemed to function perfectly well. Different ethnicities attended the same schools, worked together, served in the same army, and inter-married. Only marginal voices in nationalist circles disturbed that harmony. Within a few years in the late 1980s, it all changed. The manipulation of fears by the extremist nationalists and promotion of prejudices were key instruments in mobilising people for war (Cigar 1995). Second, there was a time in the early 1990s when it seemed that the downward spiral of violence could still be stopped by the international actors (EU, UN, and/or USA). Unfortunately, the opportunity was missed by those who could have done something. Once the tanks had started rolling and the guns roaring, it was too late. This experience with the power of hate speech and fear mongering has sensitised Bosnian Muslims to the dangers of it, hence the condemnation of prejudice and related phenomena in the document above.

\section{Bosnia and Herzegovina: Past and future}

Inter-religious dialogue often lasts as long as the topics discussed are general and universal in nature, but real challenges start once specific issues that matter in everyday life are put on the table. Things are no different in Bosnia. The truly thorny issues are related to the past and future of the Bosnian state as a homeland for its three major ethnic/religious communities and all its citizens. We shall now turn to passages in the Platform that address the topics of the root causes of the war, war crimes and victims, transitional justice and the nature of Bosnian society. First it addresses the fate of the former Yugoslavia, the causes of the war, the role of religion, and responsibility for the war and war crimes. It opens by stating that it was in the interest of the Muslims in Bosnia and Herzegovina to preserve a confederate Yugoslavia, which is why their leaders tried to safeguard one up to the end. They joined the war hesitantly, unprepared, taken by surprise, and off-guard. The Platform goes on to say that:

One of those measures was adoption of the Mosque House Rules in October 2007. These Rules are meant to prevent unauthorised use of mosque premises. 
The war itself was caused by the hegemonic projects of the political elites in the neighbouring countries ... Faith was abused during the war, but the war itself was not a religious one, as it was not fought for conversion, but primarily for the extermination of Muslims. To explain the war through centuries-old hatred is a sign of intellectual laziness or of misinformation, since neither genocide nor mass killings require centuries nor are they an obstacle to coexistence (e.g. EU).

Even though all three major peoples in $\mathrm{BiH}$ took part in the war, they are not equally responsible for it. Victim and perpetrator cannot be equated simply because both carried weapons. The criminal's use of weapons is illegitimate, while the victim has a human and divine right and even a duty to self-defence. Equating their guilt is a major insult to tens of thousands of Muslim victims, ... whose remains were moved in and out of Bosnian pits and backwoods many times over ... In addition to being immoral, equating their guilt entails the risk of rewarding crime and so encouraging its repetition.

The ICBH is convinced that Islam powerfully contributed to Bosniaks acting differently from others during the recent war.

The destruction of Yugoslavia was the beginning of all the Balkan troubles in the 1990s. The Islamic Community in Yugoslavia, which dissolved itself in 1994 in recognition of the new borders, ${ }^{6}$ was aware that Bosnian Muslims had little, if anything, to gain from such a scenario. The Community tried its best to keep Yugoslavia together, and the above statement is a reminder of that position and intended to set the record straight. It places responsibility for the war at the door of two hegemonic state projects: Greater Serbia and, to a lesser extent, Greater Croatia. ${ }^{7}$ This entails rejecting several other theses about the causes of the war, which have been promulgated by local and international actors. Serb nationalists like to blame great power conspiracies. Croatian nationalists prefer the clash of civilisations as an explanation of the Bosnian war, while many international actors dismiss the whole thing as a story of warring tribes that have hated each other for centuries (Carnegie 1996; IFIMES, 2017).

The Platform strongly denies the religious nature of the war, even if individual ICBH leaders have from time to time issued statements to the contrary by calling the conflict "Crusades" (Carnegie 1996). The confusion stems from the fact that ethnic and religious identities in Bosnia and the Balkans overlap: Serbs are mostly Orthodox Christians, Croats are mainly Catholics, while most Bosniaks are Muslims. That makes it difficult for most people to keep ethnicity and religion separate in the discussion. With sufficient attention, however, it is possible to distinguish things done for the sake of religion or of ethnicity from conduct based on political strategy or convenience. It is true that nationalist political leaders and religious leaders often worked together, adding a layer of confusion. When these leaders took different positions, it was always the politicians

6 The following Islamic communities emerged from the single IC of Yugoslavia: IC in Bosnia and Herzegovina with associated communities in Slovenia, Croatia and Serbia, IC in Montenegro, IC in Kosovo and IC in Macedonia.

7 For instance, the final ICTY judgement in the case of Duško Tadić (IT-94-1), parag. 660 reads: “As discussed, this Trial Chamber has found that an armed conflict existed in the territory of Opstina Prijedor at the relevant time and that an aspect of this conflict was a policy to commit inhumane acts against the civilian population of the territory, in particular the non-Serb population, in the attempt to achieve the creation of a Greater Serbia". For the list of relevant ICTY decisions see IFIMES, 2017. 
who prevailed over religious leaders. This is true of all the communities, which inclines one to believe that religion and religious leaders, and ethnic identity, were instrumentalised. In effect, war efforts were largely motivated by short-term political considerations. Shifting alliances among the warring parties in Bosnia are good indicators of that.

In March 1992, Bosnian Croats voted in an independence referendum together with Bosniaks/Bosnian Muslims to break with Belgrade, if and when Croatia and Slovenia left Yugoslavia. A year later, the Croats joined their forces with Serb nationalists in Bosnia and brought the Bosnian government in Sarajevo to its knees, a strange alliance forged at the behest of Zagreb despite Serb forces occupying large parts of Croatia proper at the time. In April 1994, in a further U-turn, the Croats re-joined forces with the Bosniaks because of US intervention and negotiation. Naturally, identities do not change this quickly, but politics do, which adds weight to the argument against the war being religious in nature. Turning to the victims and the issue of responsibility, the Platform states:

Muslims in $\mathrm{BiH}$ suffered the most casualties during the war, exposed to the systematic crime of genocide and so-called ethnic cleansing. Concentration camps, mass rapes, persecution, displacement, destruction of their religious and cultural buildings, and the obstruction of return, repossession, and the reconstruction of property and religious sites and of bringing criminals to justice are all parts of a general plan to eliminate Muslims across or on large parts of the territory of $\mathrm{BiH}$.

Criminal responsibility is individual, but political and moral responsibility lie with all those who helped and have been helping criminals by their votes, public appearances, consistent denial of crimes, or in other ways, throughout the war and to this very day.

Srebrenica is a huge stain on the conscience of not only Serb people within and outside of $\mathrm{BiH}$ and its Orthodox Church, but also of a major part of the international community and a portion of the international public.

The war in Bosnia made history in many ways and produced several precedents in international humanitarian law: over a hundred major war-crime cases tried by an ad hoc UN court (the International Criminal Tribunal for Former Yugoslavia, www.icty.org), the first ever judgements for genocide issued against Serb military and civilian leaders (ICTY 2001b; ICTY 2016), rape added to the list of war crimes against humanity and instruments of war (ICTY 2001a:281), DNA analysis used on a massive scale to identify missing persons (Parsons et al 2019), a database produced with the names of almost all the direct victims of war (Tokača 2020), and so on.

The major claim here, about the relative number of victims, is sometimes criticised as not in the spirit of reconciliation. The claim was included in the Platform because of attempts to deny and relativise the war crimes and equate guilt by calling for the same numbers of people from various communities to be tried for war crimes. Whenever that was not the case, the courts were denounced as political or biased. Both local and international sources have however established that over $83 \%$ of the war crimes committed were against some 33,000 Bosnian Muslim civilians (Cohen 1995; Waller 2002; Kennedy 2002; Hoare 2017:190). The claims made in the Platform about the war 
have been vindicated by evidence produced by independent sources, including multiple UN and national courts and investigative reporting or research centres. ${ }^{8}$ Sadly, despite hopes to the contrary, none of this has helped gain acceptance for the truth about the past in some political or religious circles.

In spite of its critical tone regarding the behaviour of many political and religious leaders amongst the Serbs during the 1990s, the Platform was careful not to proclaim the whole Serbian nation criminally responsible for war crimes. The case is different for political and moral responsibility. This is obviously a lesson learnt from the German experience during WWII as articulated by Karl Jaspers (Jaspers 2001). This is not however a universally accepted position within the Bosniak Muslim community. There have been voices proclaiming whole nations responsible in every sense, even going as far to claim genocide is in their genes (Dizdarević 2011).

The document specifically mentions the genocide in Srebrenica, a massacre of over 8,000 men and boys and the expulsion of all the other civilians, as epitomising everything that went wrong in Bosnia in the 1990s: the aggression on the part of the Serb nationalists, the failure of the UN to protect the civilians it promised to safeguard, and the failure of the Dutch army to defend the civilians under its protection. The 1999 UN special report concluded: "The tragedy of Srebrenica will haunt our history forever" (UN General Assembly 1999:111). Turning to the religious communities' role during the war, the Platform asserts that:

No religious community was prepared for the war, and particularly not the ICBH. Still, we believe we have passed through it honourably. ... Certainly, there have been differences not only between, but also within the religious communities with regard to preserving the integrity of religious workers under wartime conditions.

The Islamic Community recognizes the fact that there were cases of crimes and illegal actions committed in the name of Islam or Muslims ... However, the ICBH is convinced that those were and are incidents and never represented a policy ... The ICBH is particularly proud not to have been involved in acts of inciting and or covering up crimes, like the removal of the remains of bombed and burned religious sites, the relocation of mass graves, or the construction of religious structures to replace those belonging to others, etc.

The destruction of religious sites was an exceptionally shameful aspect of the recent war ... This destruction, especially in the entity of Republic of Srpska (RS), was systematic in nature, leaving only one mosque still standing in that entity by the time the Dayton Peace Agreement was signed ... It is regrettable that certain religious leaders engage in the denial of war crimes. Such denial is a transgression and a crime against their own followers, as well as an insult to the members of other religious communities.

Obstruction to the reconstruction of religious sites has been particularly shameful and worrying, as it tells us destructive forces remain powerful today. It is

In addition to the sources referred to in this text, see the archives of ICTY at https://www.icty.org/, the Belgrade Humanitarian Law Center at http://www.hlc-rdc.org/?lang=de, and the Research and Documentaion Center databases at

https://web.archive.org/web/20101203232759/http://www.idc.org.ba/index.php?option=com_content\&view=s ection\&id=35\&Itemid=126\&lang $=$ bs. 
a matter of concern that the High Representative has had to intervene to eliminate administrative obstacles to the reconstruction of religious sites in the RS.

The ICBH recognizes the jurisdiction of the ICTY, even though it is not always fully satisfied with its work and judgement, because it believes the ICTY is necessary for the truth to be objectively established ... however, this seems to be the best justice available in this world to Bosnian victims of aggression.

The 1990s in Bosnia saw the destruction of hundreds of religious sites, including most of the mosques that existed in 1990. A number of other Islamic religious structures, including graveyards and Sufi lodges, were destroyed or damaged (Walasek 2015: 153154). It is not, however, the numbers but the scope and systematic nature of destruction that is telling. Efforts were invested to eliminate all traces of Muslim presence from reality and from memory by destroying Islamic sites in areas where no war activities took place, by altering urban plans, and by changing the names of places (Riedlmayer 2002). All this testified to the nature of the destruction, which was part of a systemic plan to eradicate Muslims in $\mathrm{BiH}$ and so commit genocide. "One person can set a mosque or church on fire or mine it, without being caught. It is however impossible for one person, acting alone, to remove the debris, to alter an urban plan, or construct a parking lot or religious building of their own faith in its place," states the Platform.

The Platform thus addresses another very sad aspect of the conflict of the 1990s and the fact that some religious communities did no better than their political or military counterparts. Specifically, the Platform refers to cases where the Serbian Orthodox Church blessed the construction of churches on the site of a destroyed mosque (Divič near Zvornik) or of Muslim private property (Konjević Polje). The mosque in Divič was destroyed in 1992. A church was built in its stead in 1996. In 2001, the Human Rights Chamber of $\mathrm{BiH}$ ruled that the church should be removed. It took another seven years for the decision to be implemented. The Islamic Community had to mobilise 160,000 Euros to facilitate it (Anonymous 2011). The other case is of a church built in the courtyard of the house of a Muslim lady, Fata Orlović, near Srebrenica. On 1 October 2019, the European Court of Human Rights ruled in the case of Orlović and Others v. Bosnia and Herzegovina that the Bosnian state had three months to remove the Orthodox church built on Fata Orlović's private property (ECHR 2020). The church has still not been removed. The COVID-19 pandemic has diverted attention from the case, but the decision is expected to be implemented.

In acknowledging that war crimes were committed in the name of Islam or Muslims, the Platform may be referring to cases such as that of Kazani near Sarajevo, Grabovica in Herzegovina, as well as others. There was a total of 36 confirmed civilian victims at Kazani and Grabovica (Dizdarević 2018; ICTY 2005). There was also the case of a partial construction of a mosque at Bradina on a piece of land privately owned by a Serb, which the Islamic Community removed voluntarily at its own cost in 2008 (Eminović 2019). This acknowledgement is calibrated to ensure the Islamic Community can avoid the company of two camps: the organizers and perpetrators of mass war crimes and war crimes supporters and deniers, both of whom are equally unacceptable to the Community.

The section on peace, justice, reconciliation, and coexistence opens with a reference to a Qur'anic verse thought to provide a general framework for Muslim dealings with 
religious others. Ultimately, difference in faith is not problematic for Muslims. Justice and kindness to non-Muslims are to be practiced, states the Platform, as long as they do not attack Muslims or their property: "In its attitude toward members of other religious communities, the Islamic Community follows the Qur'anic instruction to live in peace, justice and harmony with all people of good will: 'Allah does not prohibit you from doing good and from being just to those who do not war with you because of your religion and who do not expel you from your homeland. Allah likes those who are just."' (Qur'an 60:8). The Platform then moves on to more specific issues of a local nature:

For permanent peace to be established, it is necessary that justice be satisfied and truth accepted, though some degree of peace can be established even before justice is satisfied and the truth is fully accepted ... Only just punishment of crime can break the vicious circle of evil that violence places us in every few decades. Past crimes must be punished for the sake of the future. Prayers and verbal apologies cannot substitute for justice.

Any truth commission must start from the facts established at the ICTY in the Hague and from mass graves, and its work must be complementary, not alternative to the work of the ICTY and other war crime tribunals.

There is no alternative to reconciliation, dialogue, and coexistence in a multicultural Bosnia, and the role of religious communities and churches in it is highly significant. Dialogue and cohabitation are not a tactic or an intellectual pleasure, but a strategic commitment, as we see them as the only way for our survival. Reconciliation requires courage, the first sign of which is to stop denying crimes ...

This is in response to the dilemmas over the punishment of war crimes. For a variety of reasons, there have been many proposals as to how Bosnian society should proceed, ranging from full amnesty to blind justice. While these dilemmas are neither new nor peculiar to Bosnian society, the major novelty in post-war developments in the Balkans has been the significant involvement of the so-called International Community, including the UN and its two courts, one permanent (ICJ), the other ad hoc (ICTY). The Islamic Community, while not always satisfied with the rulings of the ICTY, has given it its full support. A regional initiative for the establishment of a truth commission (https://www.recom.link/about-recom/what-is-recom/) was met with reservation because of suspicions that it might eventually replace the courts in their quest for justice.

The place of religion and religious communities in Bosnian society is sensitive for at least two reasons. First, because religion was marginalised and even at times persecuted during the Socialist period (Boeckh 2006), many religious people consider Socialist Yugoslavia as an ideological rather than a secular state, in the sense of not having been neutral or in line with the European Convention on Human Rights. Others have accepted the privatisation of religion during that period as the right approach to religion. While the current Law on the Freedom of Religion is aligned with the ECHR, there are still tensions in society. The Islamic Community rejects such an understanding of a secular state as illiberal and unacceptable. Second, religious identities are often used as proxies for ethnic identities and so targeted for discrimination. Accepting the 'religious other' as equal has proven difficult for some. The Serbian Orthodox Church was proclaimed the 
official church of the Serb-dominated Bosnian half until the High Representative decided to remove the provision from the Constitution of the Republic of Srpska (Alibašić and Begović 2017; Racius 2020). Contrary to the expectations of many, Bosnian Muslims still have a marginally more positive view of the secular state than either local Catholics or Orthodox Christians (IRI, 2017: 59). This background provides context to the following paragraphs of the Platform:

The ICBH supports a multi-religious, multi-ethnic and democratic Bosnia that is a civic society in which there is respect for freedom of religion and the independence and separation of religious institutions and the state and a civic status unrelated to religious affiliation.

The ICBH refuses to accept the interpretation according to which a secular state is reduced to the separation of religious institutions from the state, without safeguarding both individual and collective religious freedoms and the practice of religion, both privately and publicly. The ICBH openly opposes any fundamentalism, including Islamic, Catholic, Orthodox, secularist and liberal fundamentalism. The ICBH is particularly concerned at the rise of aggressive secularist or lay fundamentalism ...

The Platform goes on to praise as generally beneficial the religious communities' work together on the Law on the Freedom of Religion and the Position of Churches and Religious Communities in $\mathrm{BiH}$. Their cooperation on religious instruction in public schools is considered equally encouraging. The occasion was thus used to reiterate the Community's position that religious instruction in public schools is a right of believers as long as the textbooks and classes do not insult the beliefs of other students.

The Platform concludes by expressing shared concern with the leaders of the other religious communities for morality and traditional values in Bosnian society, which are perceived as being under threat of weakening and even becoming extinct.

\section{Conclusion}

Bosnia and Herzegovina's society is a deeply wounded and traumatised one, still far from even a semblance of consensus on its future. Exclusion, discrimination, and rejection of the religious other remain widespread. In this situation, the Islamic Community has made efforts to promote the universal values it is committed to, such as peace, justice, and coexistence. The above analysis of its Platform on dialogue hopefully sheds some light on the theological underpinnings and context of the positions taken. The violence and genocide of the 1990s bear heavily on the positions taken by this community on all issues related to human rights, international law, and the nature of Bosnian society. Although the main victims of the violence of the 1990s in the Balkans, Bosnian Muslims have nonetheless found a way to turn their suffering into an asset, using their painful experience as a backdrop against which to conduct theological reasoning on such issues as terrorism, the secular state, the equality of all religious communities, and hate crimes.

A major feature of the positions taken, is the attempt to strike a balance between extremes. Ambivalent aspects of the Islamic theological tradition are interpreted so as to comply with international legal norms. Peaceful coexistence is possible with all who are 
not aggressive towards Muslims, but that does not lead to pacifism. The victims of aggression have a right to defence and justice. Religious communities should enjoy equal legal status, but syncretism is not welcomed. Absolute justice is not achievable in this world, but it is better that attainable justice be done than impunity allowed, as that only encourages new waves of violence, and so on.

The general positioning and efforts of the Islamic Community have been recognised by many international organisations, including the Organization of Security and Cooperation, the International Organization for Migrations, and the European Union Commission, as conducive to building a multi-confessional society. Within academic circles, a number of scholars have noted the importance of this initiative. Professor Mato Zovkić, professor emeritus of Catholic Theology at the University of Sarajevo and a leading scholar and participant in inter-religious dialogue for decades, has presented the document on several occasions, apparently in the view that it "contain[s the] standard teachings of Muslim religious leaders and thinkers in BH" (Zovkić 2018:118-120; 208$209 ; 231 ; 343-344 ; 371)$. Stephen R. Goodwin has noted that the Platform "advance[s] the proper relationship between ethno-religious communities", concluding that "the situation is just that critical, that survival of the Bosnian Muslims is on the line. In order to avoid another round of violence and the eventual state collapse of BosniaHerzegovina, and to promote and sustain a multicultural and just society that supports the fundamental liberties, rights and freedoms of European society, this kind of initiative must succeed" (Goodwin 2009:297-298).

In the conclusion of their analysis of faith-based interventions for conflict transformation and lasting reconciliation in the post-conflict countries of former Yugoslavia, Sterland and Beauclerk have observed that one finds a number of similar features amongst the religious communities and leadership involved in attempts to establish institutionalised forms of religious dialogue and reconciliation, namely that

... religious institutions are ill-prepared to take on the role of peace builders and lead their congregations towards reconciliation. Regardless of the mandate for peace building they are provided with by scripture, religious communities rarely have a clear policy or strategy concerning this issue. It is instructive, that in only one case during fieldwork, that of the Islamic Community in $\mathrm{BiH}$, were religious representatives able to point to a clear written policy concerning inter-faith dialogue and reconciliation (Sterland and Beauclerk 2008:23).

I hope that this article will assist audiences outside and far beyond the Balkans in grasping and appreciating universally relevant processes that are going on in that region.

\section{BIBLIOGRAPHY}

Alibašić, Ahmet and Begović, Nedim. 2017. Reframing the relations between state and religion in post-war Bosnia: Learning to be free!, Journal of Balkan and Near Eastern Studies, 19(1), 19-34. 
Alibašić, Ahmet. 2009. A problem that does not have to be: Religious education in public schools in Bosnia and Herzegovina. In Alibašić, Ahmet et al. Religija $i$ školovanje u otvorenom društvu: Preispitivanje modela religijskog obrazovanja u Bosni i Hercegovini. Sarajevo: Fond otvoreno društvo Bosna i Hercegovina, 107110.

Alibašić, Ahmet. 2007. The Place for Others in Islam, Comparative Islamic Studies, 3(1), 98-123.

Anonymous. 2011. Zvornik: Otvorena obnovljena džamija u Diviču. Online: https://static.islamskazajednica.ba/index.php?option=com_content $\& v i e w=$ article \&id=11448:zvornik-otvorena-obnovljena-damija-u-diviu\&catid=201:aktuelnostikat\&Itemid=458 (Accessed 31 May 2020).

Assembly of the Republic of Srpska. 1992. Decision on strategic objectives of the Serbian people in Bosnia and Herzegovina, The Official Gazette of the RS, 26 November 1993, no. 22, p. 866.

B.Z. 2020. "Mračna tajna sa svadbe veka: Cecu i Arkana je venčao ozloglašeni sveštenik". Online: https://www.alo.rs/vip/zadruga-3/mracna-tajna-svadba-vekaceca-arkan-vencanje-svestenik-kacavenda-crkva/282707/vest (Accessed 31 May 2020).

Boeckh, Katrin. 2006. Vjerski progoni u Jugoslaviji 1944-1953, staljinizam u titoizmu“", Journal of Contemporary History, 38(2), 403-431.

Carnegie Endowment for International Peace. 1996. Unfinished peace: Report of the International Commission on the Balkans. Carnegie Endowment for International Peace.

Cigar, Norman. 1995. Genocide in Bosnia: The Policy of "Ethnic Cleansing". Texas A\&M University Press.

Cohen, Roger. 1995. C.I.A. Report on Bosnia blames Serbs for $90 \%$ of the war crimes, The New York Times, 9 March 1995, p. A1. Online: https://www.nytimes.com/1995/03/09/world/cia-report-on-bosnia-blames-serbsfor-90-of-the-war-crimes.html (Accessed 26 April 2020).

Dizdarević, Emina. 2018. Bosnian Activists Urge Memorial for Sarajevo Siege Killings. Online: https://balkaninsight.com/2018/10/25/bosnian-activists-call-formemorial-for-kazani-murders-10-25-2018/ (Accessed 31 May 2020.

Dizdarević, Zija. 2011. "Smutnje profesora Hafizovića", https://radiosarajevo.ba/metromahala/ja-mislim/zija-dizdarevic-smutnjeprofesora-hafizovica/58907 (Accessed 31 May 2020).

ECHR. 2020. Case of Orlović and Others V. Bosnia And Herzegovina. Online: https://hudoc.echr.coe.int/eng\#\{"itemid":["001-196155"]\} (Accessed 15 Feb. 2020).

Eminović, Hasan. 2019. “Kako je srušena džamija na Bradini”. Online: https://www.bir.ba/index.php/vijesti/bih/item/9209-kako-je-srusena-dzamija-nabradini (Accessed 15 Feb. 2020).

Goodwin, Stephen R. 2009. The central role of religion on Europe's periphery: Christian-Muslim-Muslim relations and state viability in Bosnia-Herzegovina". In World Christianity in Muslim Encounter: Essays in Memory of David A. Kerr, Vol. 2., Goodwin, Stephen R., ed. London: Continuum, 287-300. (297). 
Haass, Richard N. 2013. The irony of American strategy: Putting the Middle East in proper perspective, Foreign Affairs 92(3), 57-67. Online:

https://www.foreignaffairs.com/articles/united-states/2013-04-03/irony-americanstrategy. Accessed 19 Aug. 2020.

Hoare, Marko Attila. 2017. Bosnia and Herzegovina: genocide, justice and denial. Sarajevo: Center for Advanced Studies.

ICTY. 2001a. Prosecutor v. Dragoljub Kunarac, Radomir Kovac and Zoran Vukovic: Judgement. Online: https://www.icty.org/x/cases/kunarac/tjug/en/kun-tj010222e.pdf (Accessed 31 May 2020).

ICTY. 2001b. "Radislav Krstic becomes the first person to be convicted of genocide at the ICTY and is sentenced to 46 years imprisonment". Online: https://www.icty.org/x/cases/krstic/tjug/en/010802_Krstic_summary_en.pdf (Accessed 4 May 2020).

ICTY. 2005. Judgement in the case the Prosecutor v. Sefer Halilović. Online: https://www.icty.org/x/cases/halilovic/tjug/en/051116_halilovic_summary_en.pdf (Accessed 31 May 2020).

ICTY. 2016. Trial judgement summary for Radovan Karadzic. Online: https://www.icty.org/x/cases/karadzic/tjug/en/160324_judgement_summary.pdf (Accessed 31 May 2020).

IFIMES. 2017. "Non-acceptance of ICTY judgements and "humanisation" of crimes and criminals", 21 Dec. 2017. Online: https://www.ifimes.org/en/print/9487\#_ftn2 (Accessed 18 August 2020).

International Republican Institute, Center for Insights in Survey Research, Bosnia and Herzegovina: Attitudes on violent extremism and foreign influence, January 4 February 3, 2017. Online:

https://www.iri.org/sites/default/files/iri_bosnia_poll_february_2017.pdf (Accessed 5 April 2020).

Jaspers, Karl. 2001. The question of German guilt. Fordham University Press. Jusić, Muhamed, ed. 2018. The Ideology of takfir and violent extremism: an analysis. Sarajevo: El-Kalem.

Karup-Druško, Dženana. 2018. Radovan Karadžić, 25.2.1992: "Srpski narod se neće smiriti dok ne dospije u ono što je imao za vrijeme Nemanjića - svoju državu". Online: https://avangarda.ba/post/type-

1/679/Radovan_Karadzic_25.2.1992: “Srpski_narod_se_nece_smiriti_dok_ne_do spije_u_ono_sto_je_imao_za_vrijeme_Nemanjica_-_svoju_drzavu" (Ā 30.11.2018).

Kennedy, Michael D. 2002. Cultural formations of postcommunism: Emancipation, transition, nation and war. University of Minnesota Press.

Marković, Tomislav. 2020. "Velikosrpski vitezovi: Malo rušimo džamije, malo branimo svetinje". Online: http://balkans.aljazeera.net/vijesti/velikosrpskivitezovi-malo-rusimo-dzamije-malo-branimo-svetinje (Accessed 31 May 2020).

Mayer, Ann Elizabeth. 2018. Islam and human rights: tradition and politics. New York: Routledge. 
Parsons, T.J., Huel, R.M.L., Bajunović, Z., Rizvić, A. 2019. Large scale DNA identification: The ICMP experience, Forensic Science International: Genetics 38:236-244.

Pejanović, Mirko. 1999. Bosansko pitanje i Srbi u BiH. Sarajevo: Bosanska knjiga.

Pew Research Center. 2013. The world's Muslims: Religion, politics and society. Online: http://www.pewforum.org/Muslim/the-worlds-muslims-religion-politicssociety.aspxi (Accessed 19 April 2020).

Racius, Egdunas. 2020. "Orthodox churches and the 'othering' of Islam and Muslims in today's Balkans", Journal of Muslims in Europe 9:3, forthcoming.

Riedlmayer, András J. 2002. Destruction of cultural heritage in Bosnia-Herzegovina, 1992-1996: A post-war survey of selected municipalities. Online:

http://heritage.sensecentar.org/assets/sarajevo-national-library/sg-3-01destruction-culturale-en.pdf, accessed 18 August 2020.

Sterland, Bill and Beauclerk, John. 2008. Faith communities as potential agents for peace building in the Balkans: An analysis of faith-based interventions towards conflict transformation and lasting reconciliation in post-conflict countries of former Yugoslavia. Online:

https://www.kirkensnodhjelp.no/contentassets/c1403acd5da84d39a120090004899 173/2008/faith-communities-balkans.pdf (Accessed 6 June 2020).

Tokača, Mirsad. 2020. Bosanski atlas ratnih zločina 92-95. Online: $\mathrm{http} / / / \mathrm{www} . \mathrm{mnemos} . \mathrm{ba} / \mathrm{ba} / \mathrm{home} / \mathrm{index}$ (Accessed 31 May 2020).

Tomanić, Milorad. 2001. Srpska crkva u ratu i ratovi u njoj. Beograd: Medijska knjižara Krug.

UN General Assembly. 1999. Report of the Secretary-General pursuant to General Assembly resolution 53/35: The fall of Srebrenica. Online: https://digitallibrary.un.org/record/372298? In=en (Accessed 6 June 2020).

Walasek, Helen. 2015. Bosnia and the destruction of cultural heritage. Ashgate.

Waller, James E. 2002. Becoming evil: How ordinary people commit genocide and mass killing. Oxford University Press.

Zovkić, Mato. 2008. "Recipročnost u ekumenskim i međureligijskim odnosima u zemljama Jugoistočne Europe". In Doprinos crkava i verskih zajednica u izgradnji trajnog mira na jugoistoku Evrope, Prljević, Mirjana, ed. Beograd: Asocijacija nevladinih organizacija Jugoistočne Evrope - CIVIS, 3440.

Zovkić, Mato. 2018. Between Catholics and Muslims in Bosnia and Herzegovina. Sarajevo: Center for Advanced Studies. 